\title{
MODERN METHODS OF REASONABLE PRODUCT SUPPLY
}

\author{
Anna KULIK ${ }^{1}$ \\ Kyiv National University of Trade and Economics, Ukraine
}

\begin{abstract}
Thesis objective is to study modern methods of product supply with the purpose to determine optimal ways for their rationalization. Since the use of reasonable practices, taking into account external and internal factors under the specific conditions of product moving from the supplier to the buyer, makes the process of product supply economically viable, i.e., low costs for product transportation, ensures fast moving products, their safety and, ultimately, results in reduction of the costs of product disposal. Methodology. The study is based on theoretical methods to study this problem. System analysis method and simulation of the ways to improve were also used in the study. Results. Addressing these issues, the concept, form and stages of product supply process organization depending on the type of product have been studied; product supply management methods based on logistics concept of "demand response". Practical significance. Optimization of the principles and methods of product supply, factors affecting its organization will, in practice, contribute to the development of reasonable product delivery systems featured with economic efficiency of advanced technologies of product supply. Value/ originality. The analyzed methods of product supply management based on logistics concept of "demand response" can ensure maximum reduction of response time to the changes in demand by rapid stocktaking at those points of the market where the demand is expected to increase, which will allow to reduce the costs of bringing the product to the consumer.
\end{abstract}

Key words: product, product supply, logistics, market, demand.

JEL Classification: L11, L17, M39, L17, R22

\section{Introduction}

The topic of this article is very urgent, as product supply is the basis of the sales process making it possible to provide trade chain with the product, to develop a complex system of bringing the product to the consumer that, in general, will ensure the reduction in the price cost of the product, will make them more competitive.

The products are supplied to retail chain from a variety of sources, the main of which are manufacturing companies, distribution centers and warehouses, agricultural and procuring companies. Today, there are various forms and methods of the product supply. The right choice of forms or methods of the product of supply in this or that situation will allow reducing the costs of bringing the product to the consumer.

Product supply process should be economical i.e. low costs for product transportation, ensure fast moving product, their safety and, ultimately, result in reduction of the costs of product disposal (Dashkov, 2009).

In general, product supply process is aimed at ensuring the complete range, clear interrelation of technological processes in wholesale and retail trade, rational division of labor between them, improving efficiency and reliability of the demand study. Rational organization and technology of product supply require selection of the most efficient methods of product delivery from supplier to consumer. In practice, two basic product supply methods are widespread: decentralized shipment and centralized delivery. In this study, product supply methods organization based on logistics concept are covered as novelty elements.

The article consists of introduction, theoretical and research sections, conclusion and references.

The objective of the study: to study modern product supply methods, to determine optimal ways for their rationalization.

The tasks of the study:

- Study the concept and classification of product as the main tool of product supply;

- Identify the product as an object of logistics activities;

- Study the product supply management methods based on logistics, concept "demand response"

- Analyze the optimization methods of product supply system.

- Methods of the study:

- Theoretical method for studying this problem;

- System analysis method;

- Simulation of the ways to improve.

Corresponding author:

${ }^{1}$ Department of Trading Business and Logistics, Kyiv National University of Trade and Economics.

E-mail: kylik_anna@ukr.net 
To achieve the objective, it is necessary to ensure: continuity, rhythmicity, optimal delivery of the product to consumers. Studying commodity sources on the basis of logistics concept "demand response", which should result in active impact on range diversification and improving product quality, as the range and quality of the product play an important role not only in profit of commercial enterprise, but also in meeting the needs of the customers.

\section{Product: essence, characteristics, classification}

The object of product supply in product supply process is a product of labor which satisfies personal needs of a person and is distributed through purchase and sale, i.e., takes the form of the product. In marketing the product are considered, first, as a mean with the help of which it is possible to satisfy a certain need, and then as a product of labor manufactured for sale. These concepts are generalized in the definition provided by Philip Kotler (Kotler, Keller, 2011).

Product is anything that can satisfy need or want, can be offered to a market for attention, acquisition, or use.

Often, a product can be defined as a production representing a set of manufactured products or a separate product.

In accordance with the existing classification, all products are divided into two categories: products of individual (mass) use and production (industrial) purpose (fig. 1) (Vinogradska, 2005).

The products of individual or mass consumption are intended to satisfy personal needs of people (consumers). In this regard, they are called consumer products.

The products of production or industrial purpose are classified into three groups according to the degree of their participation in the production process: materials and parts, major construction, auxiliary materials and services.

The products of individual consumption, in their turn, are classified by the degree of life-time into four groups:

1) Long-term use - they are purchased rarely and withstand repeated use (TV, furniture, etc.);

2) Short-term use - they are acquired often, are consumed in one or several cycles of their use (food products, cosmetics, medicines, bandages);

3) Services - sale objects in the form of actions, benefits. Services may be associated with the products in their material form and may be provided in tangible form (e.g. information services);

4) Luxury products - if the products are not available, then the buyer is waiting until it appears in the market; if the buyer does not find such product, he does not buy it at all.

The demand for manufactured products is formed, as a rule, in a close interrelation with the demand for consumer goods.
For example, the demand for modern eco package equipment occurs as a consequence, firstly, of increased population demand for packages of such materials, and, secondly, the need to replace polyethylene package having environmental load.

\section{Product as logistics activity object}

Finished products, in their turn, are classified as follows: 1) means of production (consisted of instruments of labor and objects of labor used by companies-consumers);

2) consumer products (to be sold to the end consumer).

Consumer products are classified as follows:

1) fast-moving consumer products (such products are characterized by a constant demand, mostly of daily consumption, the consumers often do not think about their quality characteristics). These products are subdivided into: a) basic goods of constant demand (characterized by a constant demand, high turnover, are conditioned by the consumers' habit and action of permanent stimulating advertising);

b) impulse buying products (characterized by unstable demand, sudden purchase depending on a need);

c) emergency products (purchased when required, seasonal goods);

2) preselected products (characterized by the fact that when the consumer compares various options, he has a choice. Normally, simple distribution trade chains with a small number of points of sales are established for such products. This reduces logistics costs);

3) products of special demand (in marketing, these are luxury goods, for which the consumer is willing to pay more and spend more effort on their acquisition, these may be a prestigious brand products, fashion products etc.).

4) products of passive demand (in marketing, they are characterized by low demand, because the market is not aware of them, the manufacturer requires additional efforts in advertising costs, marketing campaigns, etc.).

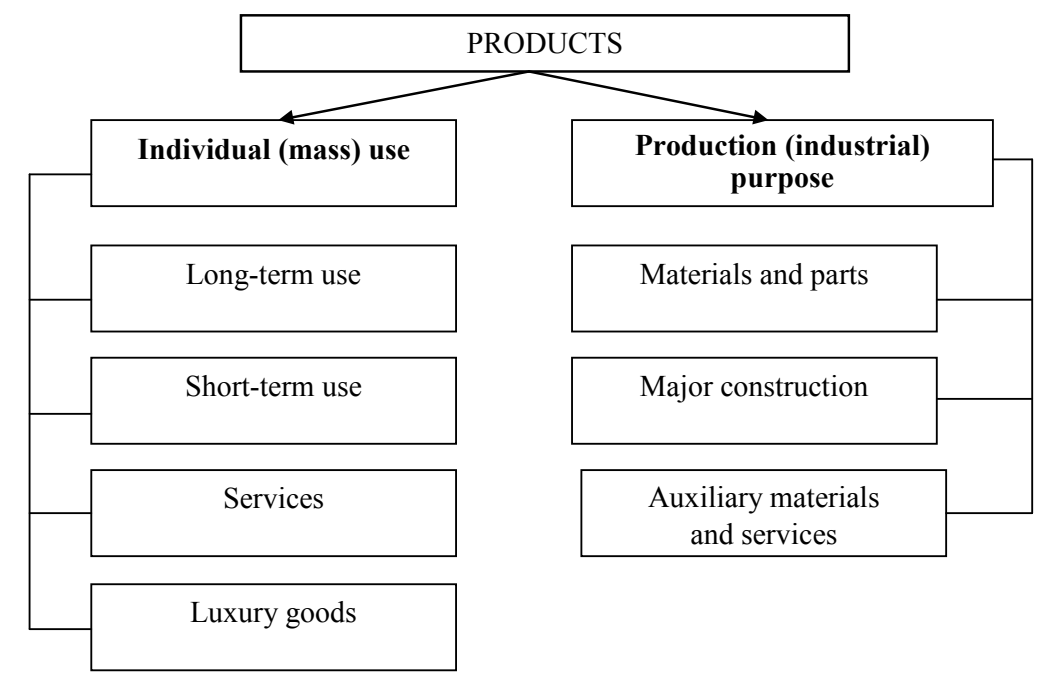

Fig. 1. Product classification 
Logistics management is determined by the life cycle of the product (Afonin, Afonina, Petrova, 2014):

1) Development stage (characterized by a long duration, related to the company's investment in scientific research and design works);

2) Launch stage of the product (long-term stage, characterized by big logistics and marketing costs, almost no profit);

3) Growthstage (this stageis determinedbytherisein demand level for the products, difficulties in logistics management - to predict demand correctly, identify key locations and points of sales, stock management, transportation, warehouses. Information inaccuracy could lead to high costs).

4) Maturity stage (growth in production rate, income level reaches its peak, in the late stage a decrease in sales volume may be observed due to the actions of competitors and emergence of new products. At this stage, the logistics management is aimed on active distribution of goods in the distribution network, sales control);

5) Stage of decline (characterized by a decrease in sales volumes and a decrease in profit caused by saturation of the market with products, appearance of new products, competing products, scientific and technical progress. The logistics management at this stage is aimed at reducing the number of points of sale, cutting logistics costs, cutting stocks at warehouses.).

Logistics cycle is a set of cycles connected by integrated logistics functions.

The components of the logistics cycle (Afonin, Afonina, Petrova, 2014):

1) order, creation of stocks;

2) processing of customer's orders, organization of purchases and order placement;

3) delivery, production;

4) collection of customer's orders and preparation of documents;

5) analysis and preparation of reporting documentation.

\section{Logistics concept «demand response»}

Back then, the logistics concept "demand response" was developed as a modification of the concept "needs/resource planning" in terms of improved response to the changes of consumer demand. The concept "demand response" is applied to minimize the response time to the changes in demand by rapid replenishment of the points of sale where the increase in demand is forecasted (Hadzhynskyi, 2003). The benefits of this concept implementation are as follows: - The possibilities to get information on customer needs, order procedures and delivery schedules of finished products help manage better the stocks in distribution;

- Knowledge of sales volume and stocks in retail chain helps manufacturers to plan deliveries more accurately; - The suppliers react quicker on fluctuations in customer demand;

- Long-term partnership relations between the manufacturers and wholesale and retail companies are established which mitigate the risks and improve the efficiency of logistics operations.

The following options for the concept "demand response" are the most known:

1. The concept of order (reorder) point uses one of the oldest of stock control and management method based on order point and statistical parameters of the product flow. For long, it could not find its application in logistics due to the inaccuracies in demand forecasting. The efficiency of this method depends considerably on the accuracy of demand forecasting, owing to this fact it was not popular for long. The emergence of telecommunications and information computer systems made it possible to study the demand at the points of sale, make more accurate forecasts, which has immediately affected the application of this concept in business practice. This was also contributed by new flexible manufacturing technologies which have significantly reduced the duration of the production and logistics cycles. The scope of application of this concept is mainly adjustment of the level of reserve stocks to equalize fluctuations in demand.

Order point is the parameter used in stock control systems and indicating the lower difference of drawing from the warehouse stocks, when the next order should be placed. The level of stock at the time of order shall be sufficient to ensure smooth operation during the period between placing the order for the products and delivery of the ordered products to the customer's warehouse.

2. Rapid Response Method is a close interaction between commercial enterprise and its suppliers to improve the promotion of products in the distribution chains.

Its essence is in planning and regulation of supplies to retail and wholesale trade companies and distribution centers. In retail trade, any sales process is supervised and controlled, information on sales volumes by articles and range is collected and transmitted through wholesalers to the manufacturers of products. Rapid Response Method implies the optimization of trade companies stocks. Application of this method reduces the stocks of finished products to the desired value, but not below the level at which the demand of the majority of buyers can be immediately met. Therewith, the time of the logistics system response to the changes in demand decreases, the stocks area concentrated and replenished in the relevant points of sales, there is flexible interaction between the partners in the integrated logistics network, stock turnover significantly increases. Main conditions that allow realizing in practice the concept of rapid response include:

- ability of the supplier to quickly restructure its manufacturing process to the production of new goods in small lots;

- information exchange based on PC communication between trade company and supplier-manufacturer;

- barcoding to enhance the level of control over the state of stocks, cutting handling costs and the costs of registration works at the warehouse.

3. Logistics concept of Rapid Response or Continuous Replenishment. This concept of continuous or frequent 
replenishment of finished goods stocks in retail companies is considered on the basis of logistics plan and agreement between the supplier, wholesale and retail trade companies on purchases and this eliminates the need to place replenishment orders. The key elements of the implementation of the concept of continuous replenishment are daily processing of sales volumes data in retail chain and product shipments from wholesalers; calculation of total demand and product range by supplier-manufacturer; continuous or frequent replenishment of stocks of retail trade company by the supplier through resellers or through direct delivery of finished products. According to this concept, efficient work requires two basic conditions: first of all, reliable information from retailers and reliable delivery of finished products should be provided, and secondly, the consignments shall comply with the maximum cargo capacity of vehicles.

4. Further development of Rapid Response strategies and Continuous Stock Replenishment is the logistics concept of automatic stock replenishment, which is an improved version of the Rapid Response method and the concept of continuous replenishment. All of them are mainly aimed at reducing the maximum response time of the logistics system to the changes in demand. The considered concept provides the suppliers of finished products with necessary set of rules for decision making on product characteristics and categories. Product category is a combination of various characteristics of the products (sizes, colors, patterns) and related products presented together in a specific retail point of sale. Applying automatic stock replenishment strategy, the supplier is able to meet the needs of the retailers in product category by eliminating the need to track individual sales and stock keeping level for fast sales. Automatic stock replenishment method encourages the efficiency of restocking by the suppliers in the retail chain, more efficient stock management, delivery reliability, compliance of stocks and demand, allows establishing long-term partnerships (Hadzhynskyi, 2003).

Despite the fact that the above strategies are aimed, to a bigger extent, at meeting retail trade requests, they allow to form the most optimal form of the relationship between manufacturers and wholesalers. Manufacturers-suppliers can better plan the deliveries when they are aware of the sales volume and the level of finished products stocks at the retailers, distribution centers and manufacturing facilities. This helps them respond more quickly to the changes in demand, decide on the placement of warehouses and production lines, set priorities in manufacturing and distribution between individual products and consumer groups.

\section{Optimization of reasonable product supply system}

Product supply is the system of measures complex of commercial and process operations to bring the product to the retail point of sales.

It includes the following processes: purchasing, delivery, acceptance and storage, preparation and sale. In practice, two forms of Product supply are applied: transit - delivery of the purchased products to the stores directly from the suppliers; warehouse - delivery of the purchased products through wholesale resellers warehouses (Mazaraki, 2002).

Entire process of reasonable Product supply system is based on the following principles: conformity to plan, rhythmicity, efficiency, centralization, feasibility, effectiveness.

Conformity to plan means that the products should be delivered based on the planned delivery schedules.

Rhythmicity means that the products should be delivered at relatively regular time intervals, creating optimal conditions for shops, warehouses and transportation.

Efficiency means to implement Product supply process in response to changes in demand.

Feasibility means minimum manpower costs, material and financial resources for delivery of products. It is achieved by the efficient use of vehicles, mechanization of handling operations, establishment of reasonable chain product movement.

Centralization means Product supply to retail chain by the efforts and means of the suppliers.

Effectiveness means use of the industrial system of Product supply using containers.

Transit Product supply form will be profitable for the manufacturer-supplier and customer (retailer) under the following circumstances: the amount of the products disposal is sufficiently big to justify the costs of direct sales; the consumers are few and are located in a relatively small territory (there is a concentration of the consumers' market); the products require highly specialized service; the volume of each delivered lot is sufficient to fill one shipping place (wagon, container); the purchaser has sufficient network of warehouses, barns; there is a rapid fluctuation in price that requires immediate approval by the purchaser (Hrynyova, 2011).

The factors affecting the organization of Product supply: production (manufacturing facilities location, specialization of production enterprises, seasonality of production); transport (state of transport routes, modes of transport); social (resettlement of population, income level); trade (size, specialization and location of the points of sale, degree of complexity of the range of products, their properties).

Purchase of goods is a component of commercial activity of trade company, which includes (Vinogradska, 2005):

- Study and forecasting of consumer demand; identification and study of product sources and suppliers of products;

- Organization of business relationships with the suppliers of products, including development and conclusion of supply contracts;

- Organization of accounting and monitoring of fulfillment of contractual obligations.

The level of service in Product supply system depends on the following factors:

- Velocity of order execution (time period from order placement to the receipt of the products); 
- Possibility of immediate delivery of the products by special order;

- Readiness to take back the delivered products, if it is found to be defective, and to replace within the shortest period with a product of good quality (and in certain cases to take a product back without asking the reasons of return); - Ensure various sizes of shipping lots according to the customer's desire;

- Skills to use the most appropriate mode of transport;

- High-performance support service;

- Well-organized warehouse network;

- Sufficient level of stocks;

- Level of prices at which the services are provided.

Efficient planning of reasonable Product supply system should include several stages:

1 - information collection;

2 - analysis of needs and possibilities (supplier and customer);

3 - strategy (form) selection of Product supply;

4 - determining the method of Product supply;

5 - operative solutions related to Product supply process;

6 - control;

7 - analysis of plan implementation;

8 - plan adjustment.

Formation of purchase volume (optimal order) is a necessary part of the reasonable Product supply system organization. Optimal order is the level at which storage area is used at the most, stock storage costs are minimized. To determination optimal order does not make sense, if the order lead time is rather long with a significant fluctuation in demand and unstable prices. In all other cases, the determination of the optimal order would reduce stock storage costs not reducing the quality of service. The calculation should ne according to the following formula (Dashkov, 2009):

$$
\mathrm{OV}=\frac{\sqrt{2 \times \mathrm{V} \times \mathrm{P}}}{\mathrm{C} \times \mathrm{S}}
$$

where OV - optimal order;

$\mathrm{V}$ - annual sales volume;

$\mathrm{P}$ - cost of one order delivery;

$\mathrm{C}$ - product unit price;

$\mathrm{S}$ - costs of unit storage at the warehouse.

Thus, reasonable organization of Product supply means to purchase the products:

1) of the required quality;

2) in the desired quantity;

3) at the right time;

4) from reliable supplier;

5) at affordable price.

\section{Conclusion}

Product supply is an important business process for the companies supplying products to a retail chain. Due to reasonably organized product supply at retail points of sale, completeness and sustainability of goods range, necessary product stocks, demand satisfaction are provided, as well as high financial and economic performance of trade companies.

In accordance with the objectives and tasks of the study, the following conclusions can be drawn:

Principal object in Product supply system is a product. Product is anything that can satisfy a need or a want, can be offered to a market for attention, acquisition, or use.

The most important principles of reasonable organization and technology of product supply are: conformity to plan, rhythmicity, efficiency, centralization, feasibility, effectiveness.

This or that source of products is chosen taking into account the factors influencing the organization of Product supply: industrial (manufacturing location, specialization of production enterprises, seasonality of production); transport (state of transport routes, modes of transport); social (resettlement of population, income level); trade (size, specialization and location of the points of sale, degree of complexity of the range of goods, their properties), as well as the goods turnover, location, state of demand and price level for the goods of different suppliers.

Analysis of the Product supply methods based on logistics concept "demand response", its advantages were identified:

- The possibility to get information about the customer needs, order procedures and finished products delivery schedules helps to manage better the stocks in distribution;

- Knowledge of sales volume and stocks in retail chain helps manufacturers to plan deliveries more accurately;

- The suppliers react more quickly to fluctuations in customer demand;

- Long-term partnership relations between the manufacturers and wholesale and retail companies are established which mitigate the risks and improve the efficiency of logistics operations.

The application of the methods of this logistics concept will allow optimizing the system of reasonable product supply, which consists in the minimization of response time to changes in demand by rapid stock replenishment at those market points where the increase in demand is forecasted.

Thus, reasonable organization of product supply means to purchase the products: 1 ) of the required quality; 2) in the desired quantity; 3 ) at the right time; 4) from reliable supplier; 5) at affordable price.

Further study of the product supply management process will allow identifying and proposing the recommendations to increase the efficiency of product supply in modern conditions of increased competition. 


\section{References}

Afonin, A.M, Afonina, V.E, Petrova, A.M. (2014). Transport logistics: freight transportation organization: manual. Moscow, FORUM: INFRA-M, 368 p.

Dashkov, P.P. (2009). Commerce and trade technology: Manual for higher school. - 9nd edition: amended and modified. Moscow, Publishing trade corporation "Dashkov \& Co", 415 p.

Hadzhynskyi, A.M. (2003). Logistics. Moscow, Publishing and book trading center «Marketing», 408 p.

Mazaraki, A.A. (2002). Economics of trade company: manual. Kiev, Khreshchatik, 800 p.

Kotler, F., Keller, K.L. (2011). Marketing management. Moscow, 14nd edition SPb., p. 246.

Vinogradska, A.M. (2005). Commercial activity of trade: Manual. Kiev, KNTEU, 280 p.

Hrynyova, V.M. (2011). Mechanisms of enterprise strategic management based on logistics. Kharkiv, Publ. HNEU, 232 p.

\section{Анна КУЛИК \\ СОВРЕМЕННЫЕ МЕТОДЫ РАЦИОНАЛЬНОГО ТОВАРОСНАБЖЕНИЯ}

Аннотация. Целью работы является изучение современных методов товароснабжения с целью определения оптимальных путей их рационализации. Так как, использование рациональных методов с учетом внешних и внутренних факторов в конкретныхусловияхпродвижениятовара отпоставщика кпокупателюделаетпроцесс товароснабжения экономичным, т.е., с минимальными затратами на транспортировку товара, обеспечивает высокую оборачиваемость товаров, их сохранность и в конечном итоге, приводит к снижению затрат на его реализацию. Методика. Исследование основано на теоретических методах изучения данной проблемы. Так же в исследовании был использован метод системного анализа и моделирование путей совершенствования. Результаты. Путем решения поставленных задач было изучено понятие, формы и этапы процесса организации товароснабжения в зависимости от вида товара; методы управления товароснабжением на основе товарно-логистической концепции «реагирование на спрос». Практическое значение. Оптимизация изученных принципов и методов товароснабжения, факторов, влияющих на его организацию, на практике будут способствовать разработке рациональной системы доставки товаров, которая отличается экономической эффективностью прогрессивных технологий товароснабжения. Значение/оригинальность. Проанализированные методы управления товароснабжением на основе товарно-логистической концепции «реагирование на спрос» способны обеспечить максимальное сокращение времени реакции на изменение спроса путем быстрого пополнения запасов в тех точках рынка, где прогнозируется увеличение спроса, что даст возможность снизить затраты на доведение товара до потребителя. 